\title{
The Information Society in the Asia-Pacific Region India and Australia
}

\author{
Sowmyanarayanan SADAGOPAN \\ Indian Institute of Information Technology, ss@iiitb.ac.in \\ and John WECKERT \\ Centre for Applied Philosophy and Public Ethics, Charles Stuart University, \\ JWeckert@csu.edu.au
}

"In both India and Australia, Governments are keenly interested in information technology, and have introduced new policies in order to encourage acceptance ... and to stimulate ICT development."

\begin{abstract}
This chapter considers just two countries in the Asia-Pacific region, India and Australia. Policies are outlined that show how the governments in these countries are attempting to encourage the IT industry, eBusiness and eGovernment, address problems of Internet access, and regulate Internet content.
\end{abstract}

Key words Information Technology (IT), information and communication technology (ICT), eBusiness, eGovernment, digital divide, Internet content

\section{INTRODUCTION}

There are a large number of countries in the Asia-Pacific region, ranging from tiny island nations to the country with the largest population on earth. It also includes economically very poor countries together with one member of the G8 group. Given this vast diversity, there can be no one "typical" 
country, but looking at India and Australia can be instructive. Neither India nor Australia is in the G8, and both are geographically remote from the economic centres of North America and Western Europe. Both have also enthusiastically embraced information technology.

\section{INDIA}

\section{Preamble}

A number of developments over the past two decades have moved ICT to centre-stage in India. There have been some Indian IT companies that have attained notable success in the global software development arena (Infosys and Wipro); some IT professionals of Indian origin made headline news in the global IT scene: Gururaj Deshpande (Founder CEO of Sycamore Networks), Arun Netravali (Head of Bell Labs), and Sabeer Bhatia (Founder of HotMail) - building on the earlier success stories of people like Vinod Khosla (Co-Founder of Sun Microsystems), and Vinod Dham (Chief Architect of Pentium Microprocessor at Intel). The Indian software and services industry achieved some major milestones in quality, with more than $70 \%$ of the SEI Level 5 quality level companies - considered the highest process quality attainment - located in India, and quantity, about half a million IT professionals in India generated business worth ten billion dollars in 2001. Of this sum, more than six billion dollars is in export. Software services export alone is expected to exceed fifty billion dollars by the year 2008. In turn, Indian IT received global attention, so much so that IT has caught the imagination of the average Indian - from the Prime Minister of the country to the man or woman on the street.

\section{Policy in India}

Until the early nineties when the central Government and the State Governments started liberalizing the economy, the Indian Republic was overly centrally administered by the Planning Commission, and that too in a socialist manner - where private sector, market economy, competition, service quality, service charges etc., had practically no place. Naturally, Government Policy played a dominant role. Unlike other industries, ICT was relatively new in India until the eighties and most of the policies of that decade aimed at freeing the industry from the control of the bureaucracy and enabling it to grow, through liberal fiscal, labour and company policies. With the industry growing in size, recent policies have been aimed at promoting sustained growth, taking IT to the masses, drawing up 
sector-specific policies, creating infrastructure, attracting FDI (Foreign Direct Investment) and even addressing sensitive issues, such as Public Sector Unit (PSU) privatisation; in the process many other issues have been addressed too, for example: liberalized foreign exchange, people exchange, labour laws, technology inputs to Government, and legislative and administrative support for wider use of IT by Government, Corporations and citizens through the IT Act, Public Key Infrastructure (PKI), Certificate Authority, De-materialization of share certificates, Transparent Electronic Stock Market, Corporate Governance, eGovernance, Government Citizen Interface and enabling wider usage of e Commerce. Based on this, the broad ICT related policies can be categorized as follows:

\section{Free Industry from shackles}

- The New Computer Policy (1984) and the earlier Computer Policy (1978), that permitted the private sector to enter computer manufacture, removed the prior permission needed for the import of computers from abroad, and drastically scaled down the duty structure to make computers affordable, so that end users could easily and affordably buy computers from both Indian and foreign manufacturers. These policies also levied "Zero duty" on software, permitting the later spectacular growth of this industry $(50 \%$ Compounded Annual Growth Rate (CAGR) over the years 1995-2000)

- Removal of the VSNL monopoly in the ISP business; prior to 1997 this was the public sector long-distance and international carrier of voice and data and the only Internet service Provider. Open the multiple Internet Gateway, including private Gateways (1999) and later the privatisation of VSNL (2000). In turn a number of private ISP's were born

- Awarding of Cellular Licenses for the private sector (1992), permitting Basic Telephony from private operators (1994) and introducing competition in the national long-distance telephony (1999). These in turn led to a healthy growth in telephone density from 0.9 in 1991 to nearly 6.0 by the year 2002 with nearly nine million cellular phone subscribers as of October 2002.

\section{Promote Sustained Growth}

Develop Infrastructure (Software Technology Parks of India): In order to get the right push for this sunrise industry the Government of India set up an autonomous body in the form of Software Technology Parks of India (STPI) with a mission to provide single point service to software and services 
companies in the form of data circuits, local "last mile" connection through radio lines, Internet Connection, International data circuits (shared and dedicated), duty exemption for import of equipment, certification for Income Tax exemption etc. It proved to be a big hit; with full income exempted from Income Tax (which is very high in India) and the STPI Registration guaranteeing it, the growing software industry got a significant cost advantage in the export market (reduced cost of infrastructure, savings in import duty, savings due to Income Tax exemption). At a later date (1994), STPI took the "virtual" view of the enterprise - any enterprise located anywhere in the identified cities (more than dozen of them) could be a Software Park (and not limited to those located in the physical premises of Export Exemption/Processing Zones, Software Parks etc).

Fiscal Incentives: Income Tax Exemption - under Sections 80HHE, $10 \mathrm{~A}$ and $10 \mathrm{~B}$ of the Income Tax Act provided a strong incentive for corporations in the IT arena to perform better, by way of freeing them from payment of very high and even cumbersome Income Tax (and the attendant paperwork, litigation and wasted management time). Also, the concept of Bonded Warehouse permitted IT equipment within identified STPI premises to be imported from anywhere in the world without payment of Import Duty (that could be high as $150 \%$ ) leading to considerable cost savings.

Other Issues: In recent years Governments (both central and state) have been formulating policies to increase the use of IT within the administration. Notable among them is the IT Act 2000 that legalized Electronic Signatures (leading to widespread PKI Infrastructure) and permitted electronic storage of documents (increased use of document management systems). Through a plan to allot 3\% of the Budget of all Government Departments (since 2000), there is now an indirect incentive for the Governments to use IT. Through a merger of the Telecommunications and IT Ministry (in the year 2001) there is better coordination between the Infrastructure Provider and the IT user interests. With increased outsourcing of ITES (IT-enabled services such as Call Centres, Back Office Processing (BPO), Medical Transcription etc.) to India, several State Governments (Karnataka, Kerala, West Bengal, Tamil Nadu) have passed legislation that frees the BPO organizations from the rather stringent labour laws, particularly in the areas of employment of women. In addition, there is competition among the states to attract BPO operations from the major world companies like GE, HSBC, Citibank etc.. There are also well-defined fiscal incentives for investment in FDI (for example, the state of Karnataka provides a fixed amount cash incentive for BPO operations reaching a size of 1000 -seater). A number of Hi-Tech Parks (with several million square feet of world-class working space in terms of connectivity, power availability and even the sheer elegance of the ambience) have been developed with participation from private sector parks. 
Many states and the central Government have even established Institutions of Higher Learning under the banner of Indian Institutes of Information Technology (IIIT's), hoping to build on the track record of the earlier string of institutions under the tag of Indian Institutes of Technology (IIT's).

\section{AUSTRALIA}

Like India, Australia is a large country, but unlike India, it has a relatively small population, and that population is concentrated along the coast, particularly in the south-east corner. This creates transportation and communication problems, and the new Information and Communication Technology (ICT) is seen by many as a way to alleviate the problem. This technology introduces a problem in itself too, in the form of fair access. With vast distances and extremely uneven population distribution, it is important to ensure that the digital divide between metropolitan and remote areas is not too great. The Australian Government and the various state and territory governments have a variety of policies, strategies and initiatives to develop the infrastructure for ICT, to encourage its use, particularly in government and business, to bridge the digital divide between city and country, and in some instances to regulate its use.

At the Australian Government level, the Department of Communications, Information Technology and the Arts [5] has responsibility for ICT. The Department provides strategic advice and professional support on information and communications technology and telecommunications, and also administers legislation, regulations, grants, and incentives to industry and the wider community.

\section{The infrastructure and the digital divide}

In 1997, the Australian telecommunications market was opened to full competition. Previously the government-owned Telstra supplied this service to all Australians. Also in 1997, the partial sale of Telstra began, and currently it is $51 \%$ government owned. Its full sale is planned but no timeframe has been mentioned. Even though the market has been opened, the government has a policy framework for supporting and encouraging the growth of telecommunications. There is also a range of laws designed to ensure the availability, quality and reasonable pricing of fixed telephones (for example, the Universal Service Obligation and the Customer Service Guarantee). The Australian Communications Authority [1] enforces these obligations. The mobile phone sector is also being supported, both with 
land-based, cellular networks, and satellite systems, with most of the population already having coverage.

This infrastructure enables all Australians to dial-up at least one ISP at un-timed local call rates (although of course, not all do this). This Internet access is narrowband, though there are also efforts to develop broadband. Currently these services are available primarily in metropolitan areas and larger rural towns.

Because of its size and uneven population distribution, the "digital divide" between rural and metropolitan areas has been a concern. Various initiatives are in place around Australia that are designed to encourage Internet use in rural areas. For example, at the National level, Government, through the Department of Transport and Regional Services has established the Rural Transaction Centres Program [6]. This programme is designed for communities with populations under 3000 , to help them establish centres that "provide access to basic transaction services, such as banking, post, phone, fax, the Internet, Centrelink Services and Medicare Easyclaim".

One of the most important initiatives by the Commonwealth Government was the Networking the Nation (NTN) programme and the Regional Telecommunications Infrastructure Fund [11]. NTN was "a Commonwealth grants program providing over $\$ 400$ million in funding to not-for-profit organisations to support activities and projects designed to address a range of telecommunications needs in regional, rural and remote Australia", and in general to improve the quality of telecommunications services in rural Australia. (This is put in the past tense because on the NTN website it says that nearly all funds have been committed.)

In New South Wales, the CTC@NSW programme is a major NSW/Commonwealth Government initiative to establish Community Technology Centres (CTCs) throughout regional NSW. CTCs in New South Wales provide a wide range of services, programs and facilities designed to support the social economic, cultural and educational life of people in small rural NSW towns. The home site CTC@NSW is managed by the NSW Office on Information Technology and is funded by the NSW Government and Networking the Nation. CTCs are located throughout NSW targeting areas that need them most, small communities with less than 3000 people. CTCs give people in rural communities: access to the latest information via the Internet, email, and videoconferencing; access to on-line government and non-government services; access to on-line education and training courses; IT enabled facilities that enable the development of programs that contribute to their social and cultural development into total communities [4].

For Victorians who are hardest to reach, the government has the Connecting Communities strategy. This is a framework to use technology to 
create and strengthen communities, and to provide the context for existing and new Internet access and training programs. It operates throughout Victoria's library branches through the Libraries On-line program. The access@schools program provides the wider community with access to Internet-equipped workstations in schools, including schools in rural and remote areas. The Victorian Government is also working on other programmes to increase Internet in rural areas uptake, including the Regional Connectivity Project, and Skills.net, a programme to ensure that everybody is able to access the resources of the Internet. Skills.net provides free or affordable Internet training and access to those Victorians who would not otherwise have such access. In particular, Skills.net is assisting technologically disadvantaged communities, including those in rural and remote Victoria [7].

This is only a small sample of Government activity designed to increase Internet use in rural areas of Australia. All State Governments are involved in some way in projects similar to those mentioned here.

\section{eBusiness}

eBusiness is being actively promoted, particularly through the National Office for the Information Economy (NOIE) [8], established by the Government in 1997. A current priority focus is the promotion of the uptake of electronic procurement and broader electronic business processes, especially by small and medium enterprises. eBusiness is seen by the Government at national level as being vital for the future economic prosperity of Australia, and is one of the main drivers for ICT policy.

Currently NOIE aims to accelerate the uptake of electronic-business tools and practices by:

- Working with industry and government to facilitate the development of collaborative eBusiness solutions;

- Identifying and influencing how standards, technology and market forces are shaping the rate at which economy-wide benefits from eBusiness are being achieved;

- Identifying and promoting the business case for the adoption of eBusiness at the firm level, within supply chains and throughout industry sectors; and

- Establishing specific strategies designed to encourage small and medium enterprises (SMEs) to get online and more deeply engaged in the use of eBusiness tools. [9] 


\section{eGovernment}

The government sees itself as having an important leadership role in enhancing the extent to which businesses and the community takes full advantage of the opportunities provided by the information economy. It is attempting to do this by maximising the opportunities provided by technology to help transform government activities. This transformation, it is hoped, will have a significant 'demonstrator' and 'pull-through' effect on Australia's wider information economy. There is an EGovernment strategy that will involve the transformation of government service delivery through the use of new technologies. It is hoped that this will provide better customer focus and access, greater availability of information, improved business processes, and efficiencies. Current NOIE projects in this area include, an eGovernment benefits study, a study regarding Access to Government Information, and an examination of Government eProcurement [10].

\section{Internet content regulation}

While the Governments in Australia are committed to encouraging and promoting ICT, there is concern about some of the material available on the Internet. As a consequence of this concern, Internet content is regulated by both the Australian and South Australian governments. On the 1st January, 2000, the Broadcasting Services Amendment (Online Services) Act 1999 [3] of the Australian Government, came into effect.

The law defines Internet content as stored information accessed over an Internet carriage service, including material on the World Wide Web, postings on newsgroups and bulletin boards, and other files that can be downloaded from an archive or library. The Act does not include ordinary email or information that is accessed in real time without being previously stored, for example chat services and voice over the Internet.

The following categories of Internet content are prohibited:

- Content which is (or would be) classified RC or X by the Classification Board.

Such content includes:

- material containing detailed instruction in crime, violence or drug use;

- child pornography;

- bestiality;

- excessively violent or sexually violent material.

- real depictions of actual sexual activity; and 
- Content hosted in Australia which is classified R and not subject to a restricted access system which complies with criteria determined by the Australian Broadcasting Authority (ABA).

Content classified $\mathrm{R}$ is not considered suitable for minors and includes:

- material containing excessive and/or strong violence or sexual violence;

- material containing implied or simulated sexual activity;

- material which deals with issues or contains depictions which require an adult perspective.[2]

The ABA was established by the Broadcasting Services Act 1992, and began operations on 5 October 1992. The Act defines the role of the regulatory authority, gives the $\mathrm{ABA}$ a range of powers and functions, and sets out explicit policy objectives.

\section{CONCLUSION}

In both India and Australia, Governments are keenly interested in information technology, and have introduced new policies in order to encourage acceptance of the technology, and to stimulate ICT development. To the extent that ICT development and acceptance is a feature of both countries, those policies appear to be bearing fruit.

\section{REFERENCES}

\section{References to Indian IT policy}

Most of the references can be seen in far greater detail at NASSCOM (National Association of Software \& Services Companies) site (http://www.nasscom.org) The Ministry of Information Technology site gives lots of details too (http://www.mit.gov.in/). Earlier, it had the name of Department of Electronics and is often referred to as DoE; there is even a DoEACC Society focusing on IT Education (http://www.doeacc.org.in/); naturally many Policy Documents would refer to DoE. Typical State Level Policies can be looked up at http://www.bangaloreit.com site that keeps Karnataka Policy as well as pointers to policies of other States in India. STPI site is another store of information (http://www.stpi.soft.net)

1. Semiconductor Integrated Circuits Act 2000

2. Information Technology Act 2000

3. Telecom Regulatory Authority of India (Amendment) Act 2000 
4. Foreign Exchange Management Act 1999 (allows software firms to freely undertake transactions on current account)

5. Telecom Regulatory Authority of India Act 1997

6. New Telecom Policy 1999 (and 1994)

7. Export Import Policy 1997-2002 (provides for license free import of computers, imports of second-hand equipment no older than 10 years and sales of up to $50 \%$ by revenue, by units under Software Technology Park, Electronic Hardware Technology Park, Export Oriented Unit, Export Processing Zone Schemes)

8. Securities and Exchange Board of India (Venture Capital Funds) Regulations 1996

9. Software Technology Park Scheme 1991

10. Computer Software Export, Development and Training Policy 1986

11. New Computer Policy 1984

12. Income Tax Act 1961, Sections $80 \mathrm{HHE}, 10 \mathrm{~A}$ and 10B (deduction of profits from export of computer software)

13. Indian Copyright Act 1957 (amended in 1995, makes copyright infringement of computer software an offence)

\section{References to Australian IT policy}

1. Australian Communications Authority, http://www.aca.gov.au

2. Australian Broadcasting Authority http://www.aba.gov.au/aba/index.htm. For a summary of prohibited Internet content see http://www.aba.gov.au/internet/complaints/complaints.htm\#what

3. Broadcasting Services Amendment (Online Services) Act 1999 http://www.aph.gov.au/parlinfo/billsnet/main.htm

4. CTC@NSW, http://www.ctc.nsw.gov.au

5. Department of Communications, Information Technology and the Arts http://www.dcita.gov.au/

6. Department of Transport and Regional Services' Rural Transaction Centres Program http://www.dotars.gov.au/rtc/

7. Multimedia Victoria - Connecting Communities, 2002. Available at http://www.mmv.vic.gov.au. See also http://www.skills.net.about/default.

8. NOIE, National Office for the Information Economy, http://www.noie.gov.au/

9. NOIE Business, http://www.noie.gov.au/projects/ebusiness/index.htm

10. NOIE Government, http://www.noie.gov.au/projects/egovernment/index.htm

11. Networking the Nation. available at http://www.dcita.gov.au/Article/0,0_1-2_3-4_106337,00.htm 